\title{
Assessment of Tumor Associated Tissue Eosinophilia (TATE) in Oral Squamous Cell Carcinoma Using Carbol Chromotrope Stain
}

\author{
Evaluación de la Eosinofilia Tisular Asociada al Tumor (TATE) en el Carcinoma \\ Oral de Células Escamosas Mediante la Tinción de Carbol Cromótropo
}

\begin{abstract}
Celestina Dawn Peter; R. Shashidara**; Vanishree C. Haragannavar"; Pradeep Samuel ${ }^{* * *}$; Sudheendra Udyavara Sridhara*; Aparna H Gopalkrishna**; Sheela Poojary*; Suhas R. Nayak \& Anu Sushanth A. ${ }^{* * * *}$
\end{abstract}

PETER, C. D.; SHASHIDARA, R; HARAGANNAVAR, V. C.; SAMUEL, P.; SRIDHARA, S. U.; GOPALKRISHNA, A. H.; POOJARY, S.; NAYAK, S. R. \& SUSHANTH, A. A. Assessment of tumour associated tissue eosinophilia (TATE) in oral squamous cell carcinoma using carbol chromotrope stain. Int. J. Odontostomat., 9(1):91-95, 2015.

ABSTRACT: Tumor related tissue eosinophilia (TATE) is a known phenomenon but its role in prognostics and correlation with size of the primary tumor is still controversial. Using a stain, like Carbol chromotrope, that targets eosinophils exclusively and vividly, offers an advantage over haematoxylin and eosin, which was used in most of the studies. Forty-nine cases of oral squamous cell carcinoma, where the TNM staging has been recorded in their history, was taken and stained with Lendrum's carbol chromotrope. Significant difference in the eosinophil count with varying size of the tumor and a parallel increase in the number noted, with increase in size. There is a corresponding increase in the number of eosinophils infiltrating the tumor with increase in size of oral squamous cell carcinoma.

KEY WORDS: TATE, eosinophils, carbol chromotrope, oral squamous cell carcinoma.

\section{INTRODUCTION}

Eosinophils are a subpopulation of granulocytes, which were first described by Wharton Jones in 1846 as coarse granule cells and later in the blood of humans, frogs, dogs and rabbits in 1879 by Dr. Paul Ehrlich as 'eosinophils'. They are multifunctional leukocytes implicated in the pathogenesis of numerous inflammatory processes, including helminthic, bacterial, and viral infections; tissue injury; tumor immunity; and allergic diseases. Since the first observation of a malignancy with marked blood eosinophilia described by Rheinbach in 1893, eosinophilia has been described in human cancers from a variety of organs (Alkhabuli \& High, 2006).

The vast majority of cancers in the oral cavity are squamous cell carcinomas, the evolution of which is influenced by host immune response cells (e.g. CD8+T cells, CD4+ T cells, natural killer cells, dendritic cells, macrophages and eosinophils). In head and neck squamous cell carcinoma, it has been reported that the presence of tissue eosinophils ranges between 22 and $89 \%$ (Bystrom et al., 2011).

The mechanism of eosinophil accumulation in cases of invasive carcinoma remains largely unknown. It has been suggested that such eosinophilic infiltration may be induced by a tumor derived eosinophil chemotactic factor. While numerous studies show that TATE is associated with a favorable prognosis, other studies show that eosinophils may play a key role in tumor invasion through activation of gelatinase, a matrix metalloproteinase involved in tumour invasion by breaking down basement membrane and extracellular matrix, which was found to be actively expressed by eosinophils. However, the exact role of TATE as a prognostic factor is inconclusive (Bystrom et al.; StahleBäckdahl \& Parks, 1993).

\footnotetext{
Department of Oral Pathology and Microbiology, Educare institute of dental sciences, Kerala, India.

** Department of Oral Pathology and Microbiology, Coorg Institute of Dental Sciences, Karnataka, India.

${ }_{* * *}^{*}$ Department of Prosthodontics, Educare institute of dental sciences, Kerala, India.

**** Department of Oral medicine and Radiology, Educare institute of dental sciences, Kerala, India.
} 
Most studies on TATE in oral squamous cell carcinoma, counted eosinophils after staining with H\&E. Intact eosinophils can usually be detected in tissue sections of tumors that are stained with hematoxylin and eosin. However, tissue eosinophils often assume an amoeboid or "medusa" cell configuration, especially in fibrous tissue, thereby making their recognition in routinely stained sections very difficult. So in this study, a lesser known stain known as Lendrum's Carbol Chromotrope was used, with a benefit that it selectively and vividly stains eosinophils.

The aim of this study is to correlate TATE in formalin fixed paraffin embedded sections of incisional biopsy specimens of oral squamous cell carcinoma, to the tumor size with the help of a special stain called Lendrum's Carbol Chromotrope.

\section{MATERIAL AND METHOD}

Forty-nine formalin fixed paraffin embedded blocks of oral squamous cell carcinoma, in which the TNM staging was previously recorded, were retrieved from the archives of our department. They were categorized into groups based on the size of the primary tumor.

The blocks were sectioned and stained with Carbol Chromotrope, a less known stain, which was given by Lendrum (1944). This stains eosinophils selectively and intensely, thereby enhancing the ease of counting.

The staining procedure was as follows. The sections were dewaxed and brought to water and then stained with Mayer's haematoxylin for $8 \mathrm{~min}$ and blueing was done. It was then placed in Carbol chromotrope staining solution at $37^{\circ} \mathrm{C}$ for $30 \mathrm{~min}$ and then washed with tap water, dehydrated, cleared and mounted. The eosinophils, by this method stained a bright red color which stood out from the rest of the tissue (Figs. 1 and 2).

The eosinophil count was done in 10 high power fields and given a score of 1 to 3 , according to the modified criteria put forward by Alkhabuli \& High (Table I). Mean score was taken for each sample and subjected to statistical analysis (Table II). Statistical analysis, ANOVA was performed, to compare the mean eosinophil count in the 3 groups.

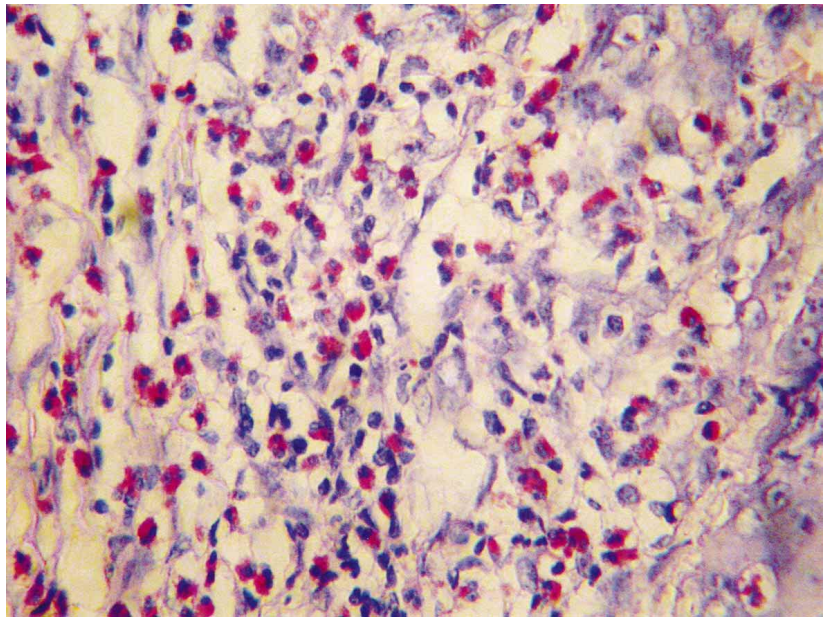

Fig. 1. Carbol chromotrope stain (40x) showing abundant bright, magenta coloured eosinophils in the tissue.

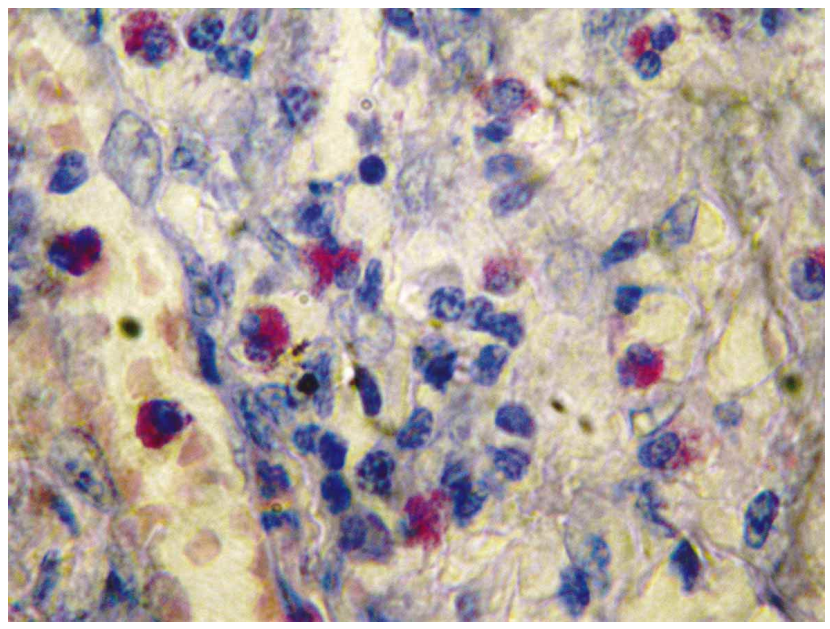

Fig. 2. Carbol chromotrope stain (100x) showing eosinophil morphology with a bilobed nucleus.

Table I. Distribution of samples according to the stage of the tumor.

\begin{tabular}{lc}
\hline Primary tumor & Number of samples \\
\hline T1 $(<2 \mathrm{~cm})$ & 19 \\
T2 $(2-4 \mathrm{~cm})$ & 15 \\
T3 $(>4 \mathrm{~cm})$ & 15 \\
\hline
\end{tabular}

Table II. Allotment of scores based on the number of eosinophils in 10 hpf.

\begin{tabular}{cc}
\hline Eosinophil count & Score \\
\hline$<50$ cells & 1 \\
$50-120$ cells & 2 \\
$>120$ cells & 3 \\
\hline
\end{tabular}


PETER, C. D.; SHASHIDARA, R; HARAGANNAVAR, V. C.; SAMUEL, P.; SRIDHARA, S. U.; GOPALKRISHNA, A. H.; POOJARY, S.; NAYAK, S. R. \& SUSHANTH, A. A. Assessment of tumour associated tissue eosinophilia (TATE) in oral squamous cell carcinoma using carbol chromotrope stain. Int. J. Odontostomat., 9(1):91-95, 2015.

\section{RESULTS}

Analysis showed a statistically significant difference in the eosinophil count between the 3 groups and a parallel increase in the eosinophil count with increase in size of the tumor (Tables III and IV).

Table III. Scores of OSCC specimens according to the tissue eosinophil count.

\begin{tabular}{cccc}
\hline & \multicolumn{3}{c}{ Scores obtained } \\
\cline { 2 - 4 } No. & Stage I & Stage II & Stage III \\
\hline 1 & 1 & 1.8 & 3 \\
2 & 1 & 2 & 1 \\
3 & 1 & 3.8 & 1.2 \\
4 & 1 & 1 & 3 \\
5 & 1.2 & 1 & 1 \\
6 & 1 & 3 & 1.2 \\
7 & 1 & 1 & 1.2 \\
8 & 1 & 2 & 3 \\
9 & 1 & 1.2 & 1 \\
10 & 1 & 1 & 1 \\
11 & 1 & 1 & 1.2 \\
12 & 1 & 3 & 3 \\
13 & 1 & 1 & 3 \\
14 & 1 & 2 & 1 \\
15 & 1 & 2 & 1.2 \\
16 & 1 & --- & --- \\
17 & 1 & --- & --- \\
18 & 1 & --- & --- \\
19 & 1 & --- & --- \\
\hline & & &
\end{tabular}

\section{DISCUSSION}

Eosinophils are a rare type of granulocyte, comprising fewer than 1 in 3,00,000 blood cells in normal individuals. They are distinguished by their tinctorial properties and abundant cytoplasmic granules that contain potent compounds which are highly toxic in vitro to helminthic and protozoan parasites, bacteria, tumor and host cells. Despite their rarity, eosinophils are involved in the pathogenesis of many important diseases, including allergies, allograft rejections, parasitic infections, celiac disease, sclerosing cholangitis, Loeffler's syndrome and retroperitoneal fibrosis (Weller \& Goetzl, 1980; Samoszuk, 1997).

Tissue eosinophilia has been described in squamous cell carcinoma of the vagina, penis, skin, nasophayrnx, larynx/pharynx, esophagus, and oral cavity; in adenocarcinomas of the stomach, large bowel and uterine body; and in transitional cell carcinoma of the bladder. There appears to be little in common between the types of tumor which show a marked TATE, save that they are almost all tumors at a body surface. Other than in Hodgkin's lymphoma, TATE is rarely seen in sarcomas, but has been reported in other forms of malignant lymphoma and in malignant fibrous histiocytoma. Metastatic tumor in lymph nodes and liver may show TATE. TATE in metastases may or may not be associated with eosinophilia in the primary tumor (Samoszuk; Martinelli-Kläy et al., 2009 ).

Intact eosinophils can usually be detected in tissue sections of tumors that are stained with hematoxylin and eosin. But tissue eosinophils often assume an amoeboid or "medusa" cell configuration, especially in fibrous tissue or inflammatory infiltrate, thereby making their recognition in routinely stained sections very difficult (Lorena et al., 2003; Lowe et al., 1981; 1984).

In this study, eosinophils were found in most cases of oral squamous cell carcinoma, with few cases showing over hundred eosinophils per high power field all three correlating with T2 or T3 stage.

Table IV. Statistical analysis ANOVA done to compare the eosinophil count between the 3 stages of oral squamous cell carcinoma.

\begin{tabular}{lrrrrrr}
\hline & \multicolumn{1}{c}{$\begin{array}{c}\mathbf{n} \\
\text { of cases }\end{array}$} & Mean & $\begin{array}{c}\text { Std. } \\
\text { Deviation }\end{array}$ & $\begin{array}{l}\text { Std. } \\
\text { Error }\end{array}$ & Minimum & Maximum \\
\cline { 2 - 7 } T1 & 19 & 1.0105 & 0.04588 & 0.01053 & 1.00 & 1.20 \\
T2 & 15 & 1.786 & 0.89592 & 0.2313 & 1.00 & 3.80 \\
T3 & 15 & 1.733 & 0.9309 & 0.2403 & 1.00 & 3.00 \\
& & Sum of & df & Mean & F & Sig. \\
& & squares & & square & & \\
\cline { 2 - 7 } & & 6.556 & 2 & 3.278 & 6.441 & 0.003 \\
\hline
\end{tabular}


PETER, C. D.; SHASHIDARA, R; HARAGANNAVAR, V. C.; SAMUEL, P.; SRIDHARA, S. U.; GOPALKRISHNA, A. H.; POOJARY, S.; NAYAK, S. R. \& SUSHANTH, A. A. Assessment of tumour associated tissue eosinophilia (TATE) in oral squamous cell carcinoma using carbol chromotrope stain. Int. J. Odontostomat., 9(1):91-95, 2015.

The eosinophils are thought to be recruited by the tumors in part by the highly potent and selective eosinophil chemo-attractant eotaxin, secreted by tumor associated eosinophils, which recruits further cells from the blood stream. A number of other factors have been shown to be potent eosinophil chemo-attractants, in vitro and in vivo, including platelet activating factor, C5a, RANTES, mcp-2, interleukin-5 and IGE. It remains unclear if the tumor cells themselves or the host inflammatory cells are responsible for the production of these eosinophilotactic compounds (Samoszuk; Martinelli-Kläy et al.; Said et al., 2005).

The functional role of eosinophils in human cancers remains even more obscure than the nature of the eosinophilotactic compounds. The anti-tumor effect of eosinophils is thought to be by the release of cytotoxic proteins, including eosinophil cationic protein, but this effect is modest at best, particularly in view of the many examples of aggressive cancers which continue to proliferate and spread even though they are infiltrated by significant number of eosinophils. A more likely possibility at this time, is that eosinophils are part of the host connective tissue response to the tissue damage created by the growing tumor, which would explain the increase in eosinophil count with increase in tumor size we found in this study. The involvement of eosinophils in connective tissue remodelling and collagen formation was first proposed by Bassett in 1962 (Samoszuk; Said et al.).

Laboratory studies in animals, seems to provide a possible explanation for this association. Pincus et al. (1987), demonstrated that eosinophils stimulate DNA synthesis in fibroblasts. Wong et al. (1991), then showed that the eosinophils express transforming growth factor $\beta 1$, which is a multifunctional cytokine known to exert potent effects on the extracellular matrix including collagen fibrosis. Ghiabi et al. (1992), showed that eosinophils infiltrating oral cancers in hamsters expressed transforming growth factor a, a multifunctional cytokine that can promote angiogenensis (Samoszuk).

These findings strongly suggest that eosinophils may be involved in the remodelling of the host connective tissue and blood vessel in response to the growing tumor which could someday make them a target for therapies designed to restrict the growth of new blood vessels and connective tissue framework in oral squamous cell carcinoma as well as some other human cancers (Samoszuk; Falconieri et al., 2008; Lowe et al., 1981,1984).

PETER, C. D.; SHASHIDARA, R; HARAGANNAVAR, V. C.; SAMUEL, P.; SRIDHARA, S. U.; GOPALKRISHNA, A. H.; POOJARY, S.; NAYAK, S. R. \& SUSHANTH, A. A. Evaluación de la eosinofilia tisular asociada al tumor (TATE) en el carcinoma oral de células escamosas mediante la tinción de carbol cromótropo. Int. J. Odontostomat., 9(1):91-95, 2015.

RESUMEN: La eosinofilia tisular asociada a tumores (TATE) es un fenómeno conocido, sin embargo su pronóstico y correlación con el tamaño del tumor primario aún es tema de controversia. El uso de cromotropo como tinción dirigida exclusivamente a los eosinófilos, ofrece una ventaja sobre la hematoxilina-eosina, que ha sido utilizada en la mayoría de los estudios. Se estudiaron células escamosas en 49 casos de carcinoma oral, con registro del estadio TNM. Las células fueron teñidas con carbol cromotropo de Lendrum. Se observó una diferencia significativa en el recuento de eosinófilos con el tamaño del tumor y un aumento paralelo en número, con el aumento de tamaño. Hay un aumento correspondiente en el número de eosinófilos que infiltran el tumor con aumento en el tamaño de carcinoma de células escamosas orales.

PALABRAS CLAVE: TATE, eosinófilos, carbol cromotropo, carcinoma oral de células escamosas.

\section{REFERENCES}

Alkhabuli, J. O. \& High, A. S. Significance of eosinophil counting in tumor associated tissue eosinophilia (TATE). Oral Oncol., 42(8):849-50, 2006.

Bystrom, J.; Amin, K. \& Bishop-Bailey, D. Analysing the eosinophil cationic protein--a clue to the function of the eosinophil granulocyte. Respir. Res., 12:10, 2011.

Falconieri, G.; Luna, M. A.; Pizzolitto, S.; DeMaglio, G.;
Angione, V. \& Rocco, M. Eosinophil-rich squamous carcinoma of the oral cavity: a study of 13 cases and delineation of a possible new microscopic entity. Ann. Diagn. Pathol., 12(5):322-7, 2008.

Ghiabi, M.; Gallagher, G. T. \& Wong, D. T. Eosinophils, tissue eosinophilia, and eosinophil-derived transforming growth factor alpha in hamster oral carcinogenesis. Cancer Res., 52(2):389-93, 1992. 
PETER, C. D.; SHASHIDARA, R; HARAGANNAVAR, V. C.; SAMUEL, P.; SRIDHARA, S. U.; GOPALKRISHNA, A. H.; POOJARY, S.; NAYAK, S. R. \& SUSHANTH, A. A.

Assessment of tumour associated tissue eosinophilia (TATE) in oral squamous cell carcinoma using carbol chromotrope stain. Int. J. Odontostomat., 9(1):91-95, 2015.

Lendrum, A. C. Fixation of Tissues from Cases of Malaria. Br. Med. J., 2(4357):44-5, 1944.

Lorena, S. C.; Dorta, R. G.; Landman, G.; Nonogaki, S. \& Oliveira, D. T. Morphometric analysis of the tumor associated tissue eosinophilia in the oral squamous cell carcinoma using different staining techniques. Histol. Histopathol., 18(3):709-13, 2003.

Lowe, D.; Jorizzo, J. \& Hutt, M. S. Tumour-associated eosinophilia: a review. J. Clin. Pathol., 34(12):1343-8, 1981.

Lowe, D.; Fletcher, C. D. \& Gower, R. L. Tumour-associated eosinophilia in the bladder. J. Clin. Pathol., 37(5):500-2, 1984.

Martinelli-Kläy, C. P.; Mendis, B. R. \& Lombardi, T. Eosinophils and oral squamous cell carcinoma: a short review. J. Oncol., 2009:310132, 2009.

Pincus, S. H.; Ramesh, K. S. \& Wyler, D. J. Eosinophils stimulate fibroblast DNA synthesis. Blood, 70(2):572-4, 1987

Said, M.; Wiseman, S.; Yang, J.; Alrawi, S.; Douglas, W.; Cheney, R.; Hicks ,W.; Rigual, N.; Loree, T.; Spiegel, G. \& Tan, D. Tissue eosinophilia: a morphologic marker for assessing stromal invasion in laryngeal squamous neoplasms. BMC Clin. Pathol., 5(1):1, 2005.

Samoszuk, M. Eosinophils and human cancer. Histol. Histopathol., 12(3):807-12, 1997.

Stahle-Bäckdahl, M. \& Parks, W. C. 92-kd gelatinase is actively expressed by eosinophils and stored by neutrophils in squamous cell carcinoma. Am. J. Pathol., 142(4):995-1000, 1993.

Weller, P. F. \& Goetzl, E. J. The human eosinophil: roles in host defense and tissue injury. Am. J. Pathol., 100(3):791$820,1980$.

Wong, D. T.; Elovic, A.; Matossian, K.; Nagura, N.; McBride, J.; Chou, M. Y.; Gordon, J. R.; Rand, T. H.; Galli, S. J. \& Weller, P. F. Eosinophils from patients with blood eosinophilia express transforming growth factor beta 1 . Blood, 78(10):2702-7, 1991.
Correspondence to:

Dr. Celestina Dawn Peter, MDS

(Oral pathology and microbiology),

Senior lecturer

Department of Oral Pathology and Microbiology

Educare Institute of Dental Sciences

College Road, Kiliyamannil Campus

Chattiparamba

Malappuram-676504, Kerala

INDIA

Email: tina24dawn@hotmail.com

Received: 26-11-2014

Accepted: 10-01-2015 